\title{
Saudi Consensus for GLP-1 RAs Switching Guidance: Consensus Report
}

\author{
Saud Alsifri' ${ }^{1}$ Hussein Elbadawi², Fahad Alsabaan ${ }^{3}$, Abdulraouf Almahfouz ${ }^{4}$, \\ Khalid Alyahya5, Eman Shesha6, Laila Abu Esba ${ }^{7}$, Meshal Alnais ${ }^{8}$, Raed Aldahash ${ }^{9}$, \\ Turky Alharbi ${ }^{10}$, Saleh Aljaser ${ }^{11}$, Emad R. Issak ${ }^{12 *}$ (i) \\ ${ }^{1}$ Endocrinology Department, Alhada \& Taif Armed Forces Hospitals, Taif, Saudi Arabia \\ ${ }^{2}$ My Clinic Medical Center, Jeddah, Saudi Arabia \\ ${ }^{3}$ Endocrinology Department, Security Forces Hospital, Riyadh, Saudi Arabia \\ ${ }^{4}$ Section of Endocrinology Department of Medicine, The King Faisal Specialist Hospital and Research Centre, Riyadh, Saudi Arabia \\ ${ }^{5}$ Pharmacy Department, Prince Sultan Military Medical City, Riyadh, Saudi Arabia \\ ${ }^{6}$ Diabetes Center, King Salman Hospital, Riyadh, Saudi Arabia \\ ${ }^{7}$ King Abdulaziz Medical City, Riyadh, Saudi Arabia \\ ${ }^{8}$ Internal Medicine and Diabetes, King Khalid Hospital, Hail, Saudi Arabia \\ ${ }^{9}$ Department of Medicine, King Abdulaziz Medical City National Guard, Riyadh, Saudi Arabia \\ ${ }^{10}$ Family Medicine Department, Prince Sultan Military Medical City, Riyadh, Saudi Arabia \\ ${ }^{11}$ King Saud bin Abdulaziz University for Health Science, Riyadh, Saudi Arabia \\ ${ }^{12}$ Medicine Department, Faculty of Medicine, Ain-Shams University, Cairo, Egypt \\ Email: ^dr.emad.r.h.issak@gmail.com
}

How to cite this paper: Alsifri, S., Elbadawi, H., Alsabaan, F., Almahfouz, A., Alyahya, K., Shesha, E., Esba, L.A., Alnais, M., Aldahash, R., Alharbi, T., Aljaser, S. and Issak, E.R. (2022) Saudi Consensus for GLP-1 RAs Switching Guidance: Consensus Report. International Journal of Clinical Medicine, 13, 22-35

https://doi.org/10.4236/ijcm.2022.131002

Received: December 9, 2021

Accepted: January 11, 2022

Published: January 14, 2022

Copyright $\odot 2022$ by author(s) and Scientific Research Publishing Inc. This work is licensed under the Creative Commons Attribution International License (CC BY 4.0).

http://creativecommons.org/licenses/by/4.0/

\begin{abstract}
Glucagon-like peptide-1 receptor agonists (GLP-1RAs) provide adequate glycemic control, weight reduction, low risk of hypoglycemia, and CV risk reduction. Their usage for type $2 \mathrm{DM}$ (T2DM) is recommended mainly when hypoglycemia or weight gain should be considered, also, whenever initial therapy is failed. There are many recent updates in the treatment paradigm of T2DM. There are many types of GLP-1RAs, with a knowledge gap regarding switching between the different types. A Saudi task force gathered to develop an explicit, evidence-based consensus for switching between GLP-1RAs, when, why, and how? This article contains the expert panel's recommendations as a contribution to complement the knowledge gap in this area from the national perspective. As an alternative to intensifying therapy, switching from one GLP-1RA to another has various advantages. Improvements in glycemic control, weight loss, adherence, and medications with established cardiovascular benefits are among them. Also, switching needs to be individualized upon many discussed factors like the dose of the previous GLP1-RA and gastrointestinal adverse effects. Discussion with patients about the why and how to switch is critical.
\end{abstract}




\section{Keywords}

Glucagon-Like Peptide-1 Receptor Agonists, Switching, Type 2 DM, Glycemic Control

\section{Introduction}

Diabetes mellitus (DM) prevalence is rising quickly not only globally (by the year 2045 it is expected to become $9.9 \%$ with a total number of 629 Million), but also in Saudi Arabia (KSA) with its great impacts on both morbidity and mortality [1] [2].

Glucagon-like peptide-1 (GLP-1) receptor agonists (GLP-1RAs) provide effective glycemic control, weight reduction, low risk of hypoglycaemia and CV risk reduction. Both the American Diabetes Association (ADA) guidelines and the ADA/European Association for the Study of Diabetes (EASD) consensus report, recommended their usage for type $2 \mathrm{DM}$ (T2DM), particularly when hypoglycemia or weight gain should be considered. In addition, they recommended their usage whenever a failure of initial therapy with metformin and comprehensive lifestyle modifications [3] [4] [5] [6].

Among the several GLP-1RAs developed, exenatide, liraglutide, semaglutide, and dulaglutide are available in the Saudi market. They have some differences in terms of their kinetics and dynamics [6]-[14]. Exenatide, liraglutide, lixisenatide, oral semaglutide are used on a daily base, either once or twice as in the case of exenatide. However, dulaglutide, exenatide extended-release and semaglutide are used once per week [15] [16].

Of all GLP-1RAs currently available, dulaglutide, liraglutide and once weekly semaglutide have demonstrated CV benefits, based on the results of several trials [9] [11] [12]. Therefore, their usage for patients with established atherosclerotic $\mathrm{CV}$ disease was recommended by the ADA. Also, other guidelines recommended their usage for those patients irrespective of glycemic control [3] [5] [17].

There are many recent updates in the treatment paradigm of T2DM in the light of new evidence available. There are many types of GLP-1RAs, with a knowledge gap regarding how to switch between the different types. Switching from one GLP-1RA to another may be beneficial and may delay the need to intensify therapy, thus avoiding an increase in the treatment burden. That may enable the reduction of the dose of concomitant oral anti-hyperglycemic drugs and/or insulin; therefore, improving the adherence to treatment [18].

We, a Saudi task force, gathered to develop an explicit, evidence-based consensus for switching between GLP-1RAs, when, why and how? This article has the recommendations of this expert panel.

\section{Insights from Available Literature}

The task force searched the medical literature for any manuscript about switch- 
ing from one GLP-1RA to another. In addition to the available randomized controlled trials and real-world studies, the task force found two eminent review articles; one review by Almandoz et al. provided advice on switching between GLP-1RAs in clinical practice; and also did another recent review was about switching between GLP-1RAs by Jain et al. [18] [19].

1) GLP-1RAs have a good impact on glycemic control as well as weight reduction

Glucose-lowering efficacy differs between GLP-1RAs. That has been observed in both clinical trials and analyses of real-world data of GLP-1RA-naïve patients [20]-[27]. The differences in HbA1c and weight reduction in GLP1-RA-naïve patients are shown in Table 1.

In addition, switching from one GLP1-RA to another led to improved glycemic control and weight reduction in both randomized controlled trials and retrospective observational studies (Table 2) [28]-[35].

These studies, therefore, demonstrate that switching between GLP-1RAs can provide additional benefits in terms of glycemic control and further weight loss.

2) GLP1-RAs have cardioprotective benefits

Some GLP1-RAs have proven cardio protective benefits like OW semaglutide, liraglutide, dulaglutide. Therefore, their indications for use have been expanded in some countries to reduce the risk of major adverse CV events in adults with T2DM and established CVD [9] [11] [12] [36] [37] [38]. On the other hand, others have not proven cardioprotective benefits like lixisenatide and exenatide ER [39] [40].

\section{Why do we need to switch from one GLP1-RA to another?}

There are many drives to switch from one GLP1-RA to another. First is the need for further glycemic control and further weight reduction. The second drive to switch is the need for cardioprotection. Other motives to switch are more safety and tolerability, patients' preferences and adherence issues, and more convenient devices [18].

One of the reasons behind the reduced efficacy of GLP1-RAs is the development of increasing antibody titer as seen in an analysis of exenatide clinical trials [41].

The available GLP1-RAs have variable safety profiles. Short-acting GLP1-RAs are more likely to cause nausea and/or vomiting. Long-acting GLP1-RAs are more likely to cause diarrhea [42] [43]. Therefore, switching from one GLP1-RA to another may help alleviate these adverse effects [44].

Poor adherence reduces the effectiveness of therapy. Improved glycemic control was observed for GLP1-RAs in patients with good adherence compared with poor adherence [45] [46] [47]. First, adherence is affected by the frequency of dosing. Several studies demonstrated that as the frequency decreases, the adherence to GLP1-RA is increased [48] [49] [50]. More adherences were observed with OW GLP1-RAs than the daily-based GLP1-RAs [51] [52] [53] [54]. 
Table 1. HbA1c and weight reduction in GLP1-RA-naïve patients.

\begin{tabular}{|c|c|c|c|}
\hline \multirow{3}{*}{ DURATION 6 [20] } & Reduction & Liraglutide $1.8 \mathrm{mg}$ & Exenatide ER $2.0 \mathrm{mg}$ \\
\hline & $\mathrm{HbAlc}$ & $1.5 \%$ & $1.3 \%$-point \\
\hline & Weight & $3.6 \mathrm{~kg}$ & $2.7 \mathrm{~kg}$ \\
\hline \multirow{3}{*}{ HARMONY 7 [21] } & Reduction & Liraglutide $1.8 \mathrm{mg}$ & Albiglutide $50 \mathrm{mg}$ \\
\hline & $\mathrm{HbA1c}$ & $1.0 \%$ & 0.8\%-point \\
\hline & Weight & $2.2 \mathrm{~kg}$ & $0.6 \mathrm{~kg}$ \\
\hline \multirow{3}{*}{ LIRA-LIXI [22] } & Reduction & Liraglutide $1.8 \mathrm{mg}$ & Lixisenatide $20 \mu \mathrm{g}$ \\
\hline & HbAlc & $1.8 \%$ & $1.2 \%$-point \\
\hline & Weight & $4.3 \mathrm{~kg}$ & $3.7 \mathrm{~kg}$ \\
\hline \multirow{3}{*}{ AWARD 6 [23] } & Reduction & Liraglutide $1.8 \mathrm{mg}$ & Dulaglutide $1.5 \mathrm{mg}$ \\
\hline & HbAlc & Same & \\
\hline & Weight & $3.6 \mathrm{~kg}$ & $2.9 \mathrm{~kg}$ \\
\hline \multirow{3}{*}{ Feher et al. } & Reduction & Liraglutide $1.8 \mathrm{mg}$ & Lixisenatide $20 \mu \mathrm{g}$ \\
\hline & \multicolumn{3}{|c|}{ Mean treatment difference } \\
\hline & HbAlc & \multicolumn{2}{|c|}{$\begin{array}{l}{[95 \% \text { confidence interval }(\mathrm{CI})]-0.3 \% \text {-point }} \\
[-0.56 ;-0.04])\end{array}$} \\
\hline \multirow{3}{*}{ SUSTAIN 3 [25] } & Reduction & OW semaglutide $1.0 \mathrm{mg}$ & Exenatide ER $2.0 \mathrm{mg}$ \\
\hline & $\mathrm{HbAlc}$ & $1.5 \%$ & $0.9 \%$ \\
\hline & Weight & $5.6 \mathrm{~kg}$ & $1.9 \mathrm{~kg}$ \\
\hline \multirow{6}{*}{ SUSTAIN 7 [26] } & Reduction & OW semaglutide $0.5 \mathrm{mg}$ & Dulaglutide $0.75 \mathrm{mg}$ \\
\hline & $\mathrm{HbAlc}$ & $1.5 \%$ & $1.1 \%$ \\
\hline & Weight & $4.6 \mathrm{~kg}$ & $2.3 \mathrm{~kg}$ \\
\hline & & OW semaglutide $1 \mathrm{mg}$ & Dulaglutide $1.5 \mathrm{mg}$ \\
\hline & $\mathrm{HbA1c}$ & $1.8 \%$ & $1.4 \%$ \\
\hline & Weight & $6.5 \mathrm{~kg}$ & $3 \mathrm{~kg}$ \\
\hline \multirow{3}{*}{ SUSTAIN 10 [27] } & Reduction & OW semaglutide $1.0 \mathrm{mg}$ & Liraglutide $1.2 \mathrm{mg}$ \\
\hline & $\mathrm{HbA} 1 \mathrm{c}$ & $1.7 \%$ & $1.0 \%$ \\
\hline & Weight & $5.8 \mathrm{~kg}$ & $1.9 \mathrm{~kg}$ \\
\hline
\end{tabular}

Table 2. HbA1c and weight reduction after switching to another GLP1-RA.

\begin{tabular}{ccc}
\hline $\begin{array}{c}\text { DURATION } 1 \\
\text { [28] }\end{array}$ & $\begin{array}{c}\text { From exenatide twice daily } 10 \mu \mathrm{g} \\
\text { Further decreases in HbA1c levels of } 0.2 \% \text {-point. }\end{array}$ \\
LEAD 6 & From exenatide twice daily $10 \mu \mathrm{g}$ & To liraglutide $1.8 \mathrm{mg}$ \\
{$[29]$} & Further decreases in HbA1c levels of $0.3 \%$-point \\
& and weight decreased by $0.9 \mathrm{~kg}$. \\
\hline
\end{tabular}


Continued

\begin{tabular}{|c|c|c|}
\hline $\begin{array}{c}\text { CIBELES } \\
\text { Project [30] }\end{array}$ & \multicolumn{2}{|c|}{$\begin{array}{l}\text { Further decreases in } \mathrm{HbA1c} \text { levels of } 0.4 \% \text {-point } \\
\text { with no significant changes in weight. }\end{array}$} \\
\hline $\begin{array}{c}\text { Visaria et al. } \\
{[31]}\end{array}$ & \multicolumn{2}{|c|}{ Further decreases in HbA1c levels of 1.3\%-point. } \\
\hline $\begin{array}{c}\text { REALiSe-DM } \\
{[32]}\end{array}$ & $\begin{array}{l}\text { From either liraglutide or dulaglutide } \\
\text { Further decreases in HbAlc lev } \\
\text { The mean reduction in weight was } 1.6\end{array}$ & $\begin{array}{l}\text { To OW semaglutide } \\
\text { of } 0.7 \% \text {-point. } \\
\text { following the switch. }\end{array}$ \\
\hline $\begin{array}{l}\text { Watanabe et al. } \\
\text { [33] }\end{array}$ & $\begin{array}{l}\text { From exenatide twice daily } \\
\text { Further decreases in HbAlc levels of } 0 \\
\text { Incidence of hypoglycemia was also } \\
\text { No significant changes }\end{array}$ & $\begin{array}{l}\text { To exenatide ER } \\
\text {-point over } 24 \text { weeks. } \\
\text { nificantly reduced. } \\
\text { reight. }\end{array}$ \\
\hline $\begin{array}{l}\text { Goncalves and } \\
\text { Bell study [34] }\end{array}$ & $\begin{array}{c}\text { From liraglutide } 1.8 \mathrm{mg} \\
\text { HbA1c decreased from } 7.46 \% \pm 1.3 \\
\text { The number of patients requiring insul } \\
\text { Weight dropped from } 110.6 \pm\end{array}$ & $\begin{array}{l}\text { To OW semaglutide } \\
\text { average dose } 0.76 \\
\text { to } 6.68 \% \pm 1.00 \% \\
\text { ropped from } 16 \text { to } 13 \text {. } \\
106 \pm 27 \mathrm{~kg} \text {. }\end{array}$ \\
\hline $\begin{array}{l}\text { Overgaard et al. } \\
\text { modeling study } \\
\qquad[35]\end{array}$ & $\begin{array}{l}\text { From another GLP-1RA } \\
\qquad \begin{array}{r}\text { More reductions in } \\
\text { Further weigh redu }\end{array}\end{array}$ & $\begin{array}{l}\text { To OW semaglutide } \\
\text { Alc } \\
\text { n. }\end{array}$ \\
\hline
\end{tabular}

Moreover, patient preference studies indicated that the injection frequency is highly considered by both injection-naïve and -experienced patients when selecting a GLP1-RA [55] [56] [57] [58] [59].

Therefore, switching from one GLP1-RA that is dosed either once or twice daily to another OW agent may improve adherence and outcomes in some patients. Despite both being OW GLP1-RAs, adherence to dulaglutide was significantly higher than exenatide ER. That indicates factors other than the frequency of dosing are also critical when considering adherence [53].

Technology-related issues are other factors affecting the decision to switch due to convenience. GLP1-RAs devices are variable. The delivery device and needle size are essential when selecting between GLP-1RAs [59]. The needle size varies between GLP1-RAs devices from large diameter (23-gauge in exenatide OW [60], 29 - 31 gauge for exenatide twice daily, and 29-gauge for dulaglutide) and a smaller diameter (32-gauge in OW semaglutide) [9] [61] [62]. A decision to switch, based on the delivery device, should only be made if a patient indicates that they have had difficulty using the injection device of their current GLP1RA. Also, another factor is the ability to allow micro-titration (i.e., titration to intermediary doses); allowing slower up-titration may help manage GI adverse effects is a significant factor [18] [63]. In addition, the degree to which the dose can be selected varies between GLP1-RA injection devices. 
In the summary difference in potency, dosage frequency and adherence, duration of action see table. In general, data suggest that long-acting GLP1-RAs have greater effects on $\mathrm{HbAlc}$, fasting plasma glucose, and body weight than those that are short-acting [13].

\section{When to Switch from One GLP1-RA to Another?}

There are several medical causes for switching. They are poor glycemic control, more weight reduction is needed, $\mathrm{CV}$ risk increased, or the presence of more advanced chronic kidney disease (CKD), and adverse effects. Non-medical causes are patient preference, cost, better technology, and insurance decrees [18] [19]. The following table illustrates these reasons and what to do in each (Table 3).

\section{How to Switch from One GLP1-RA to Another?}

An individualized approach should be considered [18] [19] once the decision has been made to switch from one GLP1-RA to another. Many factors should be considered; one of them is the reimbursement requirements, if any.

\section{Consider any contraindications}

Any contraindications or warnings should be considered when switching (Table 4).

\section{Selecting the dose to initiate}

If the patient has a history of GI adverse effects with his GLP1-RA, switch to one that enables gradual up-titration (Figure 1). Initiate it at the lowest dose. For example, $0.25 \mathrm{mg}$ in OW semaglutide and $0.75 \mathrm{mg}$ in dulaglutide. If the patient had no or minimal GI AEs with his GLP1-RA, start OW semaglutide 0.5 mg. Adjust the duration before up-titrating the new GLP-1RA according to the

Table 3. Drivers for switching and what to do in each.

\begin{tabular}{ll}
\hline \multicolumn{1}{c}{ When to switch } & \multicolumn{1}{c}{ What to do } \\
\hline Target HbA1c is not achieved because of: & Switch to an OW GLP-1RA \\
- Poor adherence & Switch to an agent with proven better glycemic efficacy \\
- Disease progression or lack of efficacy of the current & Switch to different types of GLP1-RA \\
GLP1-RA & Switch to a human GLP-1 analogue \\
- The development of anti-drug antibodies & The most effective GLP1-RA is OW semaglutide. [3] \\
The need for additional weight loss & [9] [11] [13] \\
Increased CV risk in T2DM & Dulaglutide, liraglutide or OW semaglutide \\
Established CVD & Dulaglutide \\
Multiple CV risk factors & Switch to a dulaglutide, liraglutide or OW semaglutide \\
More advanced CKD status: eGFR $<30 \mathrm{~mL} / \mathrm{min} / 1.73 \mathrm{~m}^{2}$ & [9] [10] [11] [12] [63] \\
Adverse effects & Switch to another GLP1-RA [44] \\
\hline
\end{tabular}


Switching GLP1-RA

Drivers to switch

Lack of glycemic control

Need more weight loss

Increased CV risk

Advanced CKD

GI adverse effects

\section{Tin Select}

GLP1-RA to switch to

Consider:

1. Glycemic control needed

2. GI adverse effects

3. Contraindications

Dose to start with

Consider

1. GI adverse effects of current GLP1-RA

2. Duration of current GL P1-RA

3. P atients' preferences

\begin{tabular}{|l|c|c|c|c|c|}
\hline Agent & Frequency & \multicolumn{4}{|c|}{ Equivalent Dose } \\
\hline Exenatide & OW & & & $2 \mathrm{mg}$ & \\
\hline Dulaglutide & OW & & $0.75 \mathrm{mg}$ & $1.5 \mathrm{mg}$ & \\
\hline Semaglutide & OW & & $0.25 \mathrm{mg}$ & $0.5 \mathrm{mg}$ & $1 \mathrm{mg}$ \\
\hline Liraglutide & QD & $0.6 \mathrm{mg}$ & $1.2 \mathrm{mg}$ & $1.8 \mathrm{mg}$ & \\
\hline Lixisenatide & QD & $10 \mathrm{ug}$ & $20 \mathrm{ug}$ & & \\
\hline Oral semaglutide & QD & $3 \mathrm{mg}$ & $7 \mathrm{mg}$ & $14 \mathrm{mg}$ & \\
\hline Exenatide & BID & $5 \mu \mathrm{g}$ & $10 \mu \mathrm{g}$ & & \\
\hline
\end{tabular}

Time to initiate the new GLP1-RA

Start at the same time of the current GLP 1-RA

IF daily $==>$ start next day

IF weekly $==>$ start next week

\section{iri. Switch plan}

\section{Stop current GLP1-RA and initiate new GLP1-RA}

Discuss differences between the two with the patient

If switch prompted by GI side effects

- Wait for symptoms to resolve before initiating the new agent

- Start with the lowest available dose

- Consider slower titration to maximum dose

- If needed, consider a lower maintenance dose
If switch prompted by any other reason:

- Start with equivalent (or lower) doset

- Titrate according to product instructions (if applicable)

Re-evaluate every 2 - 3 months for:
- Side effects
- Adequate titration
- Glycemic response

Figure 1. Switching plan to a new GLP-1RA. BID, twice daily; GI, gastrointestinal; GLP1-RA, glucagon-like peptide-1 receptor agonist; OW, once weekly; QD, once daily. 
Table 4. Contraindications for switching.

\begin{tabular}{|c|c|}
\hline GLP1-RA & Contraindication \\
\hline \multicolumn{2}{|l|}{ Renal impairment } \\
\hline $\begin{array}{l}\text { Majority of the available GLP1-RAs } \\
\text { except OW semaglutide, Liraglutide } \\
\text { and dulaglutide [6]-[12] [63] }\end{array}$ & $\begin{array}{c}\text { End-stage renal disease } \\
\text { (estimated glomerular filtration rate } \\
{[\mathrm{eGFR}]<15 \mathrm{~mL} / \mathrm{min} / 1.73 \mathrm{~m}^{2} \text { ) }}\end{array}$ \\
\hline $\begin{array}{l}\text { Exenatide ER and exenatide } \\
\text { twice daily [6] [8] }\end{array}$ & $\begin{array}{c}\text { Severe renal impairment } \\
\text { (creatinine clearance }<30 \mathrm{~mL} / \mathrm{min} \text { ): } \\
\text { do not use } \\
\text { Moderate renal impairment } \\
\text { (creatinine clearance } 30-50 \mathrm{~mL} / \mathrm{min} \text { ): } \\
\text { use with caution }\end{array}$ \\
\hline Lixisenatide [7] & Severe renal impairment \\
\hline Liraglutide [12] & $\begin{array}{l}\text { Renal impairment }(\mathrm{eGFR}<60) \text { : } \\
\text { caution in dose escalation }\end{array}$ \\
\hline Dulaglutide [11] & Severe renal impairment \\
\hline \multicolumn{2}{|l|}{ Diabetic retinopathy } \\
\hline $\begin{array}{c}\text { OW semaglutide and } \\
\text { dulaglutide [9] [63] [64] }\end{array}$ & $\begin{array}{c}\text { OW semaglutide and dulaglutide are } \\
\text { up-titrated more slowly (every } 2 \text { - } 3 \text { months). } \\
\text { Patients should have regular assessments } \\
\text { for retinopathy }\end{array}$ \\
\hline
\end{tabular}

presence and severity of GI AEs with the previous GLP-1RA. If GI AEs were absent or minor, then up-titrate (every two weeks). If substantial GI AEs are there, then up-titrate more slowly (every four weeks). If a patient was on the current GLP1-RA for less than one month, consider him a GLP-1RA-naïve patient. If he was on it for more than one month, consider the current GLP1-RA dose when calculating the dose of the new one [9] [11] [18] [19].

Timing of the first dose of the new GLP1-RA

The first dose of the new GLP1-RA should be at the time of the next dose of the previous GLP1-RA [18] [19].

Consider concomitant therapy when initiating the new GLP1-RA

The dose of sulphonylurea or insulin may need adjustment when switching to reduce the risk of AEs. Sulphonylurea dose should be reduced by $50 \%$, insulin by $20 \%$, and close monitoring for hypoglycemia [18] [65]. Dipeptidyl peptidase-4 inhibitors should be stopped when initiating a GLP1-RA [4].

\section{Deal with barriers to switch:}

Patients may feel that they are doing well and do not need to change. In addition, they have concerns about GI AEs. Moreover, the change of devices may be a barrier for some patients. Finally, the increased cost or reimbursement issues may be present. Discuss with the patient about the benefits obtained, and reassure that GI AEs are transient. Also, emphasize that the treatment cost and burden will not be increased [15] [18]. 


\section{Conclusion}

In conclusion, switching from one GLP1-RA to another has several benefits as an alternative to intensifying therapy. These include improving glycemic control, more weight reduction, more adherence, and drugs with proven $\mathrm{CV}$ benefits. Also, switching needs to be individualized upon many discussed factors like the dose of the previous GLP1-RA and GI AEs. Discussion with patients about the why and how to switch is critical.

\section{Conflicts of Interest}

The authors declare no conflicts of interest regarding the publication of this paper.

\section{References}

[1] International Diabetes Federation (2017) IDF Diabetes Atlas. 8th Edition, International Diabetes Federation, Brussels. http://www.diabetesatlas.org

[2] Al Dawish, M.A., Robert, A.A., Braham, R., Al Hayek, A.A., Al Saeed, A., Ahmed, R.A., et al. (2016) Diabetes Mellitus in Saudi Arabia: A Review of the Recent Literature. Current Diabetes Reports, 12, 359-368. https://doi.org/10.2174/1573399811666150724095130

[3] American Diabetes Association (2020) 9. Pharmacologic Approaches to Glycemic Treatment: Standards of Medical Care in Diabetes-2020. Diabetes Care, 43, S98S110. https://doi.org/10.2337/dc20-S009

[4] Davies, M.J., D’Alessio, D.A., Fradkin, J., et al. (2018) Management of Hyperglycemia in Type 2 Diabetes, 2018. A Consensus Report by the American Diabetes Association (ADA) and the European Association for the Study of Diabetes (EASD). Diabetes Care, 41, 2669-2701. https://doi.org/10.2337/dci18-0033

[5] Garber, A.J., Handelsman, Y., Grunberger, G., et al. (2020) Consensus Statement by the American Association of Clinical Endocrinologists and American College of Endocrinology on the Comprehensive Type 2 Diabetes Management Algorithm2020 Executive Summary. Endocrine Practice, 26, 107-139. https://doi.org/10.4158/CS-2019-0472

[6] U.S. Food \& Drug Administration (2009) Prescribing Information: BYETTA ${ }^{\oplus}$ (Exenatide) Injection.

https://www.accessdata.fda.gov/drugsatfda_docs/label/2009/021773s9s11s18s22s251 bl.pdf

[7] U.S. Food \& Drug Administration (2016) Prescribing Information: ADLYXIN ${ }^{\circledR}$ (Lixisenatide) Injection, for Subcutaneous Use.

https://www.accessdata.fda.gov/drugsatfda_docs/label/2016/208471orig1s000lbl.pdf

[8] U.S. Food \& Drug Administration (2018) Prescribing Information: BYDUREON ${ }^{\star}$ (Exenatide Extended-Release) for Injectable Suspension, for Subcutaneous Use. https://www.accessdata.fda.gov/drugsatfda_docs/label/2018/022200s026lbl.pdf

[9] U.S. Food \& Drug Administration (2020) Prescribing Information: OZEMPIC ${ }^{\circledR}$ (Semaglutide) Injection, for Subcutaneous Use.

https://www.accessdata.fda.gov/drugsatfda_docs/label/2017/209637lbl.pdf

[10] U.S. Food \& Drug Administration (2014) Prescribing Information: TANZEUM ${ }^{\circledR}$ (Albiglutide) for Injection, for Subcutaneous Use.

https://www.accessdata.fda.gov/drugsatfda_docs/label/2014/125431s000lbl.pdf 
[11] U.S. Food \& Drug Administration (2020) Prescribing Information: TRULICITY ${ }^{\circledast}$ (Dulaglutide) Injection, for Subcutaneous Use. https://www.accessdata.fda.gov/drugstfda_docs/label/2017/125469s007s008lbl.pdf

[12] U.S. Food \& Drug Administration (2017) Prescribing Information: VICTOZA ${ }^{\circledast}$ (Liraglutide) Injection, for Subcutaneous Use. https://www.accessdata.fda.gov/drugsatfda_docs/label/2017/022341s027lbl.pdf

[13] Htike, Z.Z., Zaccardi, F., Papamargaritis, D., Webb, D.R., Khunti, K. and Davies, M.J. (2017) Efficacy and Safety of Glucagon-Like Peptide-1 Receptor Agonists in Type 2 Diabetes: A Systematic Review and Mixed Treatment Comparison Analysis. Diabetes, Obesity and Metabolism, 19, 524-536. https://doi.org/10.1111/dom.12849

[14] Witkowski, M., Wilkinson, L., Webb, N., Weids, A., Glah, D. and Vrazic, H. (2018) A Systematic Literature Review and Network Meta-Analysis Comparing Once-Weekly Semaglutide with Other GLP-1 Receptor Agonists in Patients with Type 2 Diabetes Previously Receiving 1-2 Oral Antidiabetic Drugs. Diabetes Therapy, 9, 1149-1167. https://doi.org/10.1007/s13300-018-0424-2

[15] Gentilella, R., Pechtner, V., Corcos, A. and Consoli, A. (2019) Glucagon-Like Peptide-1 Receptor Agonists in Type 2 Diabetes Treatment: Are They All the Same? Diabetes/Metabolism Research and Reviews, 35, e3070. https://doi.org/10.1002/dmrr.3070

[16] Hughes, S. and Neumiller, J.J. (2020) Oral Semaglutide. Clinical Diabetes, 38, 109-111. https://doi.org/10.2337/cd19-0079

[17] Cosentino, F., Grant, P.J., Aboyans, V., et al. (2020) 2019 ESC Guidelines on Diabetes, Pre-Diabetes, and Cardiovascular Diseases Developed in Collaboration with the EASD. European Heart Journal, 41, 255-323.

https://doi.org/10.1093/eurheartj/ehz486

[18] Jain, A.B., Ali, A., Gorgojo Martínez, J.J., et al. (2021) Switching between GLP-1 Receptor Agonists in Clinical Practice: Expert Consensus and Practical Guidance. European Heart Journal, 75, e13731. https://doi.org/10.1111/ijcp.13731

[19] Almandoz, J.P., Lingvay, I., Morales, J. and Campos, C. (2020) Switching between Glucagon-Like Peptide-1 Receptor Agonists: Rationale and Practical Guidance. Clinical Diabetes, 38, 390-402. https://doi.org/10.2337/cd19-0100

[20] Buse, J.B., Nauck, M., Forst, T., et al. (2013) Exenatide Once Weekly versus Liraglutide Once Daily in Patients with Type 2 Diabetes (DURATION-6): A Randomised, Open-Label Study. The Lancet, 381, 117-124.

https://doi.org/10.1016/S0140-6736(12)61267-7

[21] Pratley, R.E., Nauck, M.A., Barnett, A.H., et al. (2014) Once-Weekly Albiglutide versus Once-Daily Liraglutide in Patients with Type 2 Diabetes Inadequately Controlled on Oral Drugs (HARMONY 7): A Randomised, Open-Label, Multicentre, Non-Inferiority Phase 3 Study. The Lancet Diabetes \& Endocrinology, 2, 289-297. https://doi.org/10.1016/S2213-8587(13)70214-6

[22] Nauck, M., Rizzo, M., Johnson, A., Bosch-Traberg, H., Madsen, J. and Cariou, B. (2016) Once-Daily Liraglutide versus Lixisenatide as Add-On to Metformin in Type 2 Diabetes: A 26-Week Randomized Controlled Clinical Trial. Diabetes Care, 39, 1501-1509. https://doi.org/10.2337/dc15-2479

[23] Dungan, K.M., Povedano, S.T., Forst, T., et al. (2014) Once-Weekly Dulaglutide versus Once-Daily Liraglutide in Metformin-Treated Patients with Type 2 Diabetes (AWARD-6): A Randomised, Open-Label, Phase 3, Non-Inferiority Trial. The Lancet, 384, 1349-1357. https://doi.org/10.1016/S0140-6736(14)60976-4

[24] Feher, M., Vega-Hernandez, G., Mocevic, E., et al. (2017) Effectiveness of Liraglu- 
tide and Lixisenatide in the Treatment of Type 2 Diabetes: Real-World Evidence from the Health Improvement Network (THIN) Database in the United Kingdom. Diabetes Therapy, 8, 417-431. https://doi.org/10.1007/s13300-017-0241-Z

[25] Ahmann, A.J., Capehorn, M., Charpentier, G., et al. (2018) Efficacy and Safety of Once-Weekly Semaglutide versus Exenatide ER in Subjects with Type 2 Diabetes (SUSTAIN 3): A 56-Week, Open-Label, Randomized Clinical Trial. Diabetes Care, 41, 258-266. https://doi.org/10.2337/dc17-0417

[26] Pratley, R.E., Aroda, V.R., Lingvay, I., et al. (2018) Semaglutide versus Dulaglutide Once Weekly in Patients with Type 2 Diabetes (SUSTAIN 7): A Randomised, Open-Label, Phase 3b Trial. The Lancet Diabetes \& Endocrinology, 6, 275-286.

https://doi.org/10.1016/S2213-8587(18)30024-X

[27] Capehorn, M.S., Catarig, A.M., Furberg, J.K., et al. (2020) Efficacy and Safety of Once-Weekly Semaglutide $1.0 \mathrm{mg}$ vs Once-Daily Liraglutide $1.2 \mathrm{mg}$ as Add-On to 1-3 Oral Antidiabetic Drugs in Subjects with Type 2 Diabetes (SUSTAIN 10). Diabetes \& Metabolism, 46, 100-109. https://doi.org/10.1016/j.diabet.2019.101117

[28] Buse, J.B., Drucker, D.J., Taylor, K.L., et al. (2010) DURATION-1: Exenatide Once Weekly Produces Sustained Glycemic Control and Weight Loss over 52 Weeks. Diabetes Care, 33, 1255-1261. https://doi.org/10.2337/dc09-1914

[29] Buse, J.B., Sesti, G., Schmidt, W.E., et al. (2010) Switching to Once-Daily Liraglutide from Twice-Daily Exenatide Further Improves Glycemic Control in Patients with Type 2 Diabetes Using Oral Agents. Diabetes Care, 33, 1300-1303. https://doi.org/10.2337/dc09-2260

[30] Gorgojo-Martínez, J.J., Gargallo-Fernandez, M.A., Brito-Sanfiel, M. and Lisbona-Catalan, A. (2018) Real-World Clinical Outcomes and Predictors of Glycaemic and Weight Response to Exenatide Once Weekly in Patients with Type 2 Diabetes: The CIBELES Project. European Heart Journal, 72, e13055. https://doi.org/10.1111/ijcp.13055

[31] Visaria, J., Dang-Tan, T., Petraro, P.V., Nepal, B.K. and Willey, V. (2019) Real-World Effectiveness of Semaglutide in Early Users from a U.S. Commercially Insured (CI) and Medicare Advantage (MA) Population. Diabetes, 68, 1006-P. https://doi.org/10.2337/db19-1006-P

[32] Jain, A., Kanters, S., Khurana, R., Kissock, J., Severin, N. and Stafford, S. (2021) Real World Efficacy Analysis of Switch from Liraglutide or Dulaglutide to Semaglutide in Type 2 Diabetes Mellitus: REALiSe-DM Study. Diabetes Therapy, 12, 527-536. https://doi.org/10.1007/s13300-020-00984-X

[33] Watanabe, Y., Saisho, Y., Inaishi, J., et al. (2020) Efficacy and Safety of Once Weekly Exenatide after Switching from Twice-Daily Exenatide in Patients with Type 2 Diabetes. Journal of Diabetes Investigation, 11, 382-388.

https://doi.org/10.1111/jdi.13146

[34] Goncalves, E. and Bell, D.S. (2019) Efficacy of Semaglutide versus Liraglutide in Clinical Practice. Diabetes \& Metabolism, 46, 515-517. https://doi.org/10.1016/j.diabet.2019.10.001

[35] Overgaard, R.V., Lindberg, S.Ø. and Thielke, D. (2019) Impact on HbA1c and Body Weight of Switching from Other GLP-1 Receptor Agonists to Semaglutide: A Model-Based Approach. Diabetes, Obesity and Metabolism, 21, 43-51. https://doi.org/10.1111/dom.13479

[36] Marso, S.P., Daniels, G.H., Brown-Frandsen, K., et al. (2016) Liraglutide and Cardiovascular Outcomes in Type 2 Diabetes. The New England Journal of Medicine, 375, 311-322. https://doi.org/10.1056/NEJMoa1603827 
[37] Gerstein, H.C., Colhoun, H.M., Dagenais, G.R., et al. (2019) Dulaglutide and Cardiovascular Outcomes in Type 2 Diabetes (REWIND): A Double-Blind, Randomised Placebo-Controlled Trial. The Lancet, 394, 121-130. https://doi.org/10.1016/S0140-6736(19)31149-3

[38] Marso, S.P., Bain, S.C., Consoli, A., et al. (2016) Semaglutide and Cardiovascular Outcomes in Patients with Type 2 Diabetes. The New England Journal of Medicine, 375, 1834-1844. https://doi.org/10.1056/NEJMoa1607141

[39] Pfeffer, M.A., Claggett, B., Diaz, R., et al. (2015) Lixisenatide in Patients with Type 2 Diabetes and Acute Coronary Syndrome. The New England Journal of Medicine, 373, 2247-2257. https://doi.org/10.1056/NEJMoa1509225

[40] Holman, R.R., Bethel, M.A., Mentz, R.J., et al. (2017) Effects of Once-Weekly Exenatide on Cardiovascular Outcomes in Type 2 Diabetes. The New England Journal of Medicine, 377, 1228-1239. https://doi.org/10.1056/NEJMoa1612917

[41] Fineman, M.S., Mace, K.F., Diamant, M., et al. (2012) Clinical Relevance of AntiExenatide Antibodies: Safety, Efficacy and Cross-Reactivity with Long-Term Treatment. Diabetes, Obesity and Metabolism, 14, 546-554.

https://doi.org/10.1111/j.1463-1326.2012.01561.x

[42] Bettge, K., Kahle, M., Abd El Aziz, M.S., Meier, J.J. and Nauck, M.A. (2017) Occurrence of Nausea, Vomiting and Diarrhoea Reported as Adverse Events in Clinical Trials Studying Glucagon-Like Peptide-1 Receptor Agonists: A Systematic Analysis of Published Clinical Trials. Diabetes, Obesity and Metabolism, 19, 336-347. https://doi.org/10.1111/dom.12824

[43] Nauck, M.A. and Meier, J.J. (2019) Management of Endocrine Disease: Are All GLP-1 Agonists Equal in the Treatment of Type 2 Diabetes? European Journal of Endocrinology, 181, R211-R234. https://doi.org/10.1530/EJE-19-0566

[44] Bain, S.C. and McKenna, J. (2010) Clinical Experience with Liraglutide. International Journal of Clinical Practice. Supplement, 167, 44-48. https://doi.org/10.1111/j.1742-1241.2010.02494.x

[45] Lin, L.K., Sun, Y., Heng, B.H., Chew, D.E.K. and Chong, P.N. (2017) Medication Adherence and Glycemic Control among Newly Diagnosed Diabetes Patients. BMJ Open Diabetes Research \& Care, 5, e000429. https://doi.org/10.1136/bmjdrc-2017-000429

[46] Aikens, J.E. and Piette, J.D. (2013) Longitudinal Association between Medication Adherence and Glycaemic Control in Type 2 Diabetes. Diabetic Medicine, 30, 338-344. https://doi.org/10.1111/dme.12046

[47] Hamersky, C.M., Fridman, M., Gamble, C.L. and Iyer, N.N. (2019) Injectable Antihyperglycemics: A Systematic Review and Critical Analysis of the Literature on Adherence, Persistence, and Health Outcomes. Diabetes Therapy, 10, 865-890. https://doi.org/10.1007/s13300-019-0617-3

[48] Coleman, C.I., Limone, B., Sobieraj, D.M., et al. (2012) Dosing Frequency and Medication Adherence in Chronic Disease. Journal of Managed Care \& Specialty Pharmacy, 18, 527-539. https://doi.org/10.18553/jmcp.2012.18.7.527

[49] Giorgino, F., Penfornis, A., Pechtner, V., Gentilella, R. and Corcos, A. (2018) Adherence to Antihyperglycemic Medications and Glucagon-Like Peptide 1-Receptor Agonists in Type 2 Diabetes: Clinical Consequences and Strategies for Improvement. Patient Preference and Adherence, 12, 707-719.

https://doi.org/10.2147/PPA.S151736

[50] Kruk, M.E. and Schwalbe, N. (2006) The Relation between Intermittent Dosing and Adherence: Preliminary Insights. Clinical Therapeutics, 28, 1989-1995. 
https://doi.org/10.1016/j.clinthera.2006.12.011

[51] Qiao, Q., Ouwens, M.J., Grandy, S., Johnsson, K. and Kostev, K. (2016) Adherence to GLP-1 Receptor Agonist Therapy Administered by Once-Daily or Once-Weekly Injection in Patients with Type 2 Diabetes in Germany. Diabetes, Metabolic Syndrome and Obesity, 9, 201-205. https://doi.org/10.2147/DMSO.S99732

[52] Nguyen, H., Dufour, R. and Caldwell-Tarr, A. (2017) Glucagon-Like Peptide-1 Receptor Agonist (GLP-1RA) Therapy Adherence for Patients with Type 2 Diabetes in a Medicare Population. Advances in Therapy, 34, 658-673.

https://doi.org/10.1007/s12325-016-0470-y

[53] Alatorre, C., Fernández Landó, L., Yu, M., et al. (2017) Treatment Patterns in Patients with Type 2 Diabetes Mellitus Treated with Glucagon-Like Peptide-1 Receptor Agonists: Higher Adherence and Persistence with Dulaglutide Compared with Once-Weekly Exenatide and Liraglutide. Diabetes, Obesity and Metabolism, 19, 953-961. https://doi.org/10.1111/dom.12902

[54] Mody, R., Huang, Q., Yu, M., et al. (2019) Adherence, Persistence, Glycaemic Control and Costs among Patients with Type 2 Diabetes Initiating Dulaglutide Compared with Liraglutide or Exenatide Once Weekly at 12-Month Follow-Up in a Real-World Setting in the United States. Diabetes, Obesity and Metabolism, 21, 920-929. https://doi.org/10.1111/dom.13603

[55] Qin, L., Chen, S., Flood, E., et al. (2017) Glucagon-Like Peptide-1 Receptor Agonist Treatment Attributes Important to Injection-Experienced Patients with Type 2 Diabetes Mellitus: A Preference Study in Germany and the United Kingdom. Diabetes Therapy, 8, 335-353. https://doi.org/10.1007/s13300-017-0237-8

[56] Qin, L., Chen, S., Flood, E., et al. (2017) Glucagon-Like Peptide-1 Receptor Agonist Treatment Attributes Important to Injection-Naive Patients with Type 2 Diabetes Mellitus: A Multinational Preference Study. Diabetes Therapy, 8, 321-334. https://doi.org/10.1007/s13300-017-0230-2

[57] Gelhorn, H.L., Poon, J.L., Davies, E.W., Paczkowski, R., Curtis, S.E. and Boye, K.S. (2015) Evaluating Preferences for Profiles of GLP-1 Receptor Agonists among Injection-Naive Type 2 Diabetes Patients in the UK. Patient Preference and Adherence, 9, 1611-1622. https://doi.org/10.2147/PPA.S90842

[58] Polonsky, W.H., Fisher, L., Hessler, D., Bruhn, D. and Best, J.H. (2011) Patient Perspectives on Once-Weekly Medications for Diabetes. Diabetes, Obesity and Metabolism, 13, 144-149. https://doi.org/10.1111/j.1463-1326.2010.01327.x

[59] Thieu, V.T., Robinson, S., Kennedy-Martin, T., Boye, K.S. and Garcia-Perez, L.E. (2019) Patient Preferences for Glucagon-Like Peptide 1 Receptor-Agonist Treatment Attributes. Patient Preference and Adherence, 13, 561-576. https://doi.org/10.2147/PPA.S187907

[60] AstraZeneca (2020) BYDUREON Frequently Asked Questions. https://www.bydureon.com/pen/frequently-asked-questions.html

[61] Amylin Pharmaceuticals Inc. and Eli Lilly and Company (2006) Byetta Pen User Manual.

https://www.accessdata.fda.gov/drugsatfda_docs/label/2006/021773s005lbl.pdf

[62] Matfin, G., Van Brunt, K., Zimmermann, A.G., Threlkeld, R. and Ignaut, D.A. (2015) Safe and Effective Use of the Once Weekly Dulaglutide Single-Dose Pen in Injection-Naïve Patients with Type 2 Diabetes. Journal of Diabetes Science and Technology, 9, 1071-1079. https://doi.org/10.1177/1932296815583059

[63] European Medicines Agency (2019) Summary of Product Characteristics: OZEMPIC ${ }^{\circledast}$ (Semaglutide). Hyperlink. https://www.ema.europa.eu/en 
https://www.ema.europa.eu/en/documents/product-information/ozempic-epar-pro duct-information_en.pdf

[64] American Diabetes Association (2020) 11. Microvascular Complications and Foot Care: Standards of Medical Care in Diabetes-2020. Diabetes Care, 43, S135-S151. https://doi.org/10.2337/dc20-S011

[65] Rodbard, H.W., Lingvay, I., Reed, J., et al. (2018) Semaglutide Added to Basal Insulin in Type 2 Diabetes (SUSTAIN 5): A Randomized, Controlled Trial. The Journal of Clinical Endocrinology \& Metabolism, 103, 2291-2301.

https://doi.org/10.1210/jc.2018-00070 